\begin{tabular}{|c|c|}
\hline $\begin{array}{l}\text { 研究助成 } \\
\text { 成果報告 }\end{array}$ & $\begin{array}{c}\text { ホソカワ粉体工学振興財団年報 } \\
\text { Hosokawa Powder Technology Foundation ANNUAL REPORT }\end{array}$ \\
\hline
\end{tabular}

13111

\section{Cu-Sb-Bi 系硫化物ナノ結晶の精密合成と 塗布型太陽電池への応用 \\ Synthesis of Cu-Sb-Bi Sulfide Nanocrystals for Solution-Processed Solar Cells}

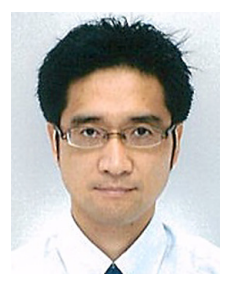

木田 徹也

\author{
研究代表者 Research leader：木田 徹也 Tetsuya KIDA \\ 熊本大学大学院自然科学研究科 教授 \\ Graduate school of Science and Technology, Kumamoto University, Professor \\ E-mail: tetsuya@kumamoto-u.ac.jp
}

共同研究者 Co-researcher: 末廣 智 Satoshi SUEHIRO

一般財団法人ファインセラミックスセンター 材料技術研究所 研究員

Materials Research and Development Laboratory, Japan Fine Ceramics Center,

Researcher

\title{
抄録
}

$\mathrm{P}$ 型半導体の中でも，銅を含むカルコパライト型の半導体，例えば $\mathrm{CuInSe}_{2}$ and $\mathrm{Cu}_{2} \mathrm{ZnSnS}_{4}$ は太陽 電池材料として大きな注目を集めており，それらをナノサイズ化した半導体ナノ結晶は湿式法で薄 膜を作製できる大きなメリットを有する。そこで本研究では, 新しい半導体材料として銅ーアンチ モンー硫黄（CAS）に着目し, $\mathrm{CuSbS}_{2}, \mathrm{Cu}_{3} \mathrm{SbS}_{4}$ and $\mathrm{Cu}_{12} \mathrm{Sb}_{4} \mathrm{~S}_{13}$ といったナノ結晶を合成し，その 太陽電池材料としての特性を調べた。高沸点有機溶媒中での金属錯体の熱分解により，上記の半導 体ナノ結晶を合成した。各種分析（XRD， UV-Vis-NIR，TEM，光電子分光測定）を行った結果, 合成したものは，目的とする組成と結晶構造を有するナノ結晶であることが確認できた。合成した ナノ結晶を用いて $\mathrm{ITO} / \mathrm{ZnO} / \mathrm{CdS} / \mathrm{CuSbS}_{2} / \mathrm{Au}$ の構造の太陽電池を作製し, その光応答を調べたところ, $\mathrm{CuSbS}_{2}$ については明瞭な光電変換特性を示すことがわかった。一方で, $\mathrm{Cu}_{3} \mathrm{SbS}_{4}$ and $\mathrm{Cu}_{12} \mathrm{Sb}_{4} \mathrm{~S}_{13}$ は 光電変換特性を示さなかった。

\begin{abstract}
P-type nanocrystals of copper-based chalcogenides such as $\mathrm{CuInSe}_{2}$ and $\mathrm{Cu}_{2} \mathrm{ZnSnS}_{4}$ have attracted increasing attention in photovoltaics because of their prospects for cheap solution-processed solar cells. In this study, copper-antimony-sulfide (CAS) nanocrystals including $\mathrm{CuSbS}_{2}, \mathrm{Cu}_{3} \mathrm{SbS}_{4}$ and $\mathrm{Cu}_{12} \mathrm{Sb}_{4} \mathrm{~S}_{13}$ were synthesized by a hot-injection method. The crystal phase control was achieved by changing the reaction temperature and starting precursor ratios. Crystal morphologies significantly depended on the crystal phase; $\mathrm{CuSbS}_{2}$ and $\mathrm{Cu}_{12} \mathrm{Sb}_{4} \mathrm{~S}_{13}$ were rod-like crystals while $\mathrm{Cu}_{3} \mathrm{SbS}_{4}$ was angulate crystals. Photoemission yield measurements
\end{abstract}


and UV-Vis-NIR spectroscopy revealed differences in the electronic structures of the three phases. Devices coupling CAS particulate films with dense CdS layers exhibited a diode like behavior, suggesting the formation of pn junction between them. Devices based on the structure of ITO/ZnO/CdS/ $\mathrm{CuSbS}_{2} / \mathrm{Au}$ exhibited a PV response with the power conversion efficiency of $0.01 \%$ under simulated sunlight, while devices with $\mathrm{Cu}_{3} \mathrm{SbS}_{4}$ and $\mathrm{Cu}_{12} \mathrm{Sb}_{4} \mathrm{~S}_{13}$ showed no PV response. Although the obtained efficiency is very low for practical applications, improving the film quality by sintering and optimizing the thickness would further improve the performance.

\section{研 究目 的}

化石燃料・原子力に代わり，太陽エネルギー の有効利用が大きな課題となっている. そこで, 低コストで製造できる有機太陽電池が期待され ているが，耐久性にそしいという大きな問題が ある。その解決策の 1 つとして，同じく塗布法 により製造できる無機ナノ結晶を用いた太陽電 池が有機太陽電池に代わるものとして期待され ている. 粒径 $10 \mathrm{~nm}$ 以下の半導体ナノ結晶を使 えば，簡易な塗布法によって成膜でき，高価な 真空装置が無くても半導体膜を製造できる.

最近申請者は, 上記太陽電池の大きな可能性 に惹かれ, 半導体ナノ結晶の精密合成と塗布型 太陽電池の研究を開始した。これまでに下図に 示す $\mathrm{CuInS}_{2}(\mathrm{p}$ 型）と $\mathrm{CdS}(\mathrm{n}$ 型）ナノ結晶を 積層した構造のセルにおいて光電変換特性を得 ている。しかし、これまで報告された電池では, 毒性の高い $\mathrm{Cd}, \mathrm{Pb}, \mathrm{Se}$ 等や稀少資源の In を 含むため，更なる材料開発が不可欠である。そ こで申請者は，希少金属や毒性の高い元素を含 まない $\mathrm{CuSbS}_{2}$ と $\mathrm{CuBiS}_{2}$ に着目した。両化合 物は太陽電池に適した高い光吸収係数と 1.4$1.5 \mathrm{eV}$ の禁制帯幅を有することが報告されてい るが, その太陽電池への利用はほとんど検討さ れてない,そこで本研究では, 湿式化学法によっ て高品質の $\mathrm{CuSbS}_{2}$ と $\mathrm{CuBiS}_{2}$ のナノ結晶を合 成し, それを用いて薄膜を調製する手法の確立 を目指す，化学的手法によれば膜の組成コント ロールは容易であり，また真空プロセスに比べ て大きなコストダウンも図れる。本研究ではさ らに，調製したナノ結晶膜を用いて印刷法によ
り太陽電池を作製し，この新材料の可能性を明 らかにした，今回は特に $\mathrm{CuSbS}_{2}$ ナノ結晶を用 いた塗布型太陽電池について詳細な検討を行っ た。

\section{研究成果の概要}

\section{背景}

$\mathrm{CdTe}^{[1]}, \mathrm{Cu}(\mathrm{In}, \mathrm{Ga}) \mathrm{Se}_{2}{ }^{[2]}$ といった既存の化合 物薄膜太陽電池材料は希少, 有毒元素を含んで いる事が問題となっている，そこで将来の太陽 電池材料を見据えて, 希少ではなく, 有毒元素 を含まない材料の探索が求められている. 近年, Kumar と Person は密度汎用関数を用いた第一 原理計算 ${ }^{[3]}$ により, $\mathrm{CuSbS}_{2}$ と $\mathrm{CuBiS}_{2}$ は既存 の $\mathrm{p}$ 型半導体太陽電池光吸収材料の代替材料に なり得ることが報告されている. 彼らの報告に よると $\mathrm{CuSbS}_{2}$ は直接遷移型のバンドギャップ 1.6-1.8 eV と強い光吸収係数 $\alpha>10^{4} \mathrm{~cm}^{-1}$ ) を持 ち, $\mathrm{CuInS}_{2}$ や $\mathrm{CuZnSnS}_{4}$ の太陽電池光吸収材料 と同等の性能が期待できる. 他の研究グループ も理論計算 ${ }^{[4]}$ より $\mathrm{CuSbS}_{2}$ の太陽電池としての 可能性を予測している。 また, $\mathrm{CuSbS}_{2}$ は構成 元素に稀少元素や有毒元素を含んでいないた め, 新しい低コスト太陽電池材料として期待で きる。

過去, $\mathrm{CuSbS}_{2}$ 薄膜は噴霧熱分解法 ${ }^{[5]}$, 真空 蒸着 ${ }^{[6]}$, 化学溶液析出法 ${ }^{[7]}$, 電着 - 硫化法 ${ }^{[8]}$, 熱蒸着法 ${ }^{[9]}$ といった方法で成膜されている. しかし， $\mathrm{CuSbS}_{2}$ を用いた太陽電池の報告例は 少なく, Lazcano らは ${ }^{[10]}$ 化学溶液析出法を用 いて $\mathrm{CuSbS}_{2}$ 薄膜を成膜し, 太陽電池を作製し 
ているが，擬似太陽光照射下 $\left(1 \mathrm{~kW} / \mathrm{cm}^{2}\right)$ で $3451 \mathrm{mV}, 0.18 \mathrm{~mA} / \mathrm{cm}^{2}$ といった性能が報告さ れているに過ぎない，そこで本研究では，申請 者らがこれまでに得たナノ結晶の合成手法とデ バイス作製技術を利用して $\mathrm{CuSbS}_{2}$ ナノ結晶の 太陽電池光吸収層としての可能性を評価した。

\section{$\mathrm{CuSbS}_{2}$ ナノ結晶の合成}

$\mathrm{CuSbS}_{2}$ ナノ結晶は文献 ${ }^{[15]}$ を参考に少し修正 を加えてホット・インジェクション法により合 成した。 $\mathrm{Cu}(\mathrm{II})$ アセチルアセトナートと $\mathrm{Sb}(\mathrm{III})$ アセテート各 $1.5 \mathrm{mmol}$ と $5 \mathrm{ml}$ のオレイルアミ ンを三ッロフラスコに加え，真空下で $120^{\circ} \mathrm{C}$ 30 分間加熱した後, $200^{\circ} \mathrm{C}$ まで昇温した。昇 温後 $200^{\circ} \mathrm{C}$ で $1 \mathrm{~mol}$ の硫黄 $10 \mathrm{ml}$ に溶かした硫 黄ーオレイルアミンを，上記の溶液にインジェ クションし，その後 $200^{\circ} \mathrm{C} て ゙ ~ 60$ 分間加熱した. $80^{\circ} \mathrm{C}$ 付近まで自然冷却した後，2-プロパノー ルとヘキサンを加えて $50 \mathrm{~mL}$ とし， $6000 \mathrm{rpm}$ で5 分間遠心分離した。生じた沈殿にへキサン $20 \mathrm{~mL}$ とオレイルアミン 3 滴を加え, $1500 \mathrm{rpm}$ で 1 分間遠心分離することで粒子のサイズ選択 を行った。分離液を2分割し，それぞれに2プロパノールを加えて $50 \mathrm{~mL}$ としたで, $6000 \mathrm{rpm}$ で 5 分間遠心分離を行った。生じた 沈殿をトルエンに分散させることでインク溶液 （0.15 g/ml）を調製した。

\section{物性評価}

図 1（a）に透過電子顕微鏡（TEM）像と走 査電子顕微鏡（SEM）像を示す。合成した粒 子は $50 \mathrm{~nm} \times 1 \mu \mathrm{m}$ のロッド形状であった。こ のナノロッド形状の粒子はソルボサーマル法 ${ }^{[9]}$ やホットインジェクション法 ${ }^{[15]}$ を用いて合成 報告されたものとほぼ同じ形状であった。図 1 (b-d）に ITO ガラス基板上に $\mathrm{CuSbS}_{2}$ インク溶 液を用いてドロップキャストにより成膜した $\mathrm{CuSbS}_{2}$ 膜の SEM 像を示す。TEM で観察され たナノロッドが集合して緻密膜を形成している ことがわかる。また結晶には，異方形状のロッ ドやピンホールが見られた。

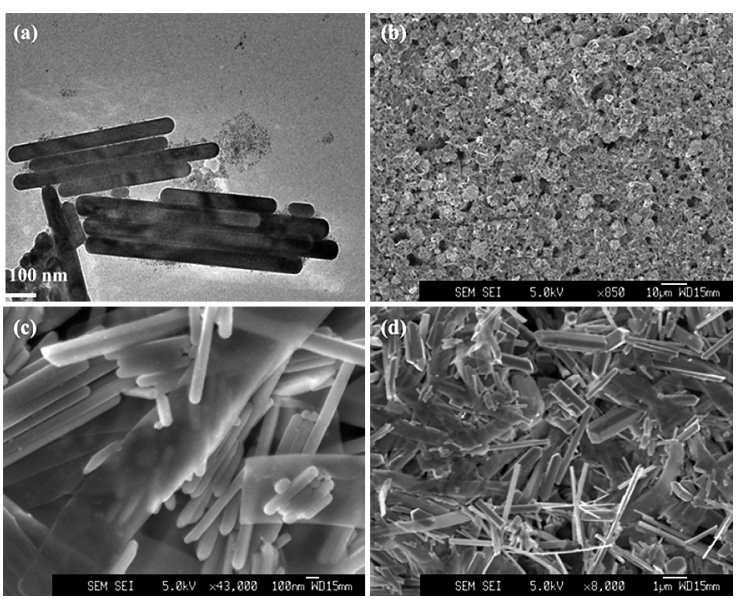

図 $1 \mathrm{CuSbS}_{2}$ ナノロッドの TEM（a） 及び $\mathrm{CuSbS}_{2}$ 膜の表面 SEM 像（b）-（d）

(a)

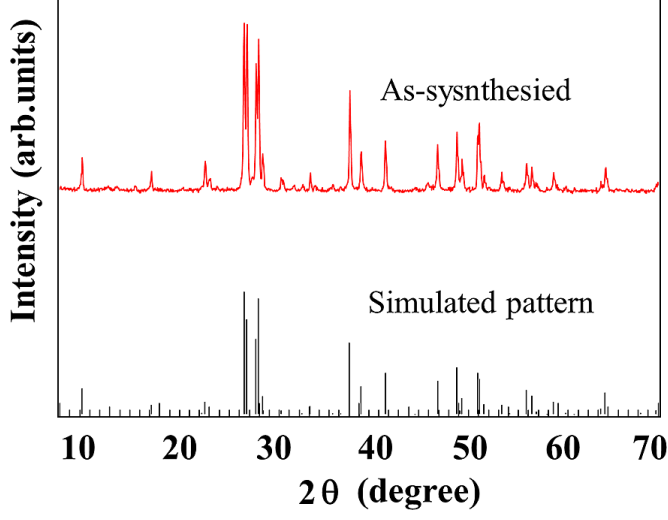

図 $2 \mathrm{CuSbS}_{2}$ ナノロッドの XRD パターン

図 2（a）に合成した $\mathrm{CuSbS}_{2}$ ナノロッドの $\mathrm{XRD}$ パターンを示す。合成したナノロッド の XRD パターンはシュミレーションした Chalcostibite 構造の XRD パターン (space group: Pnma, $a=6.018, b=3.7958, c=14.498$ and $\left.\alpha=\beta=\gamma=90^{\circ}\right)$ とよく一致した。これは調製し たナノロッド粒子が $\mathrm{CuSbS}_{2}$ であることを示し ている.

図 3 に $\mathrm{CuSbS}_{2}$ ナノロッドの UV-Vis-NIR ス ペクトルを示す. $\mathrm{CuSbS}_{2}$ ナノロッドの吸収端 立ち上がりが約 $1000 \mathrm{~nm}$ の位置で見られた。次 に $(\alpha h v)^{2}$ vs $h v$ プロットよりバンドギャップを 見積もった。エネルギー $1.6 \mathrm{eV}$ 以降の曲線を 直線で外挿し, $x$ 軸との交点から $E_{\mathrm{g}}$ は $\sim 1.5 \mathrm{eV}$ 


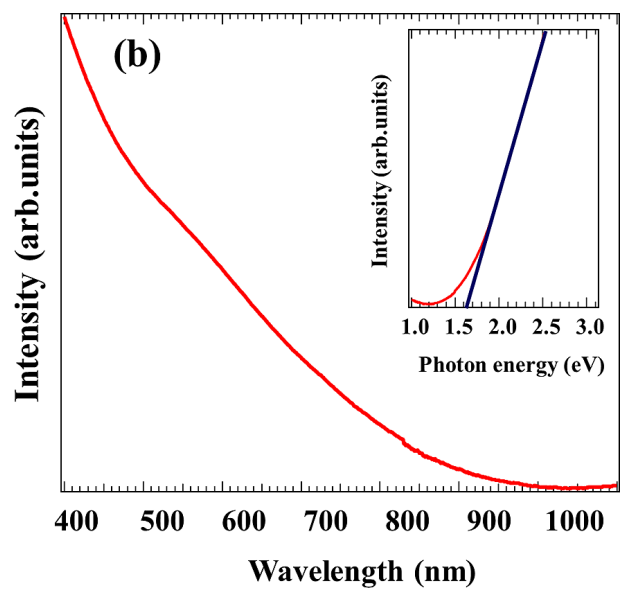

図 $3 \mathrm{CuSbS}_{2}$ ナノロッドの UV-Vis-NIR スペクトル

と算出した. $\mathrm{CuSbS}_{2}$ ナノロッドの平均的な元 素組成比はICP-AES を用いて $\mathrm{Cu}_{1.0} \mathrm{Sb}_{1.0} \mathrm{~S}_{1.7}$ で あることがわかった，硫黄元素が少し欠損した 状態であった。

\section{太陽電池作製と評価}

まず $\mathrm{ITO} / \mathrm{CuSbS}_{2} / \mathrm{CdS} / \mathrm{Al}$ 構造のデバイスを作 製し，その特性を評価した. ITO ガラス基板

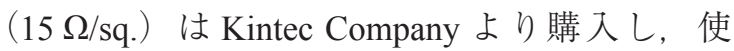
用前にアセトンや純粋で 5 分間超音波洗浄を 行った。 $\mathrm{CuSbS}_{2}$ 膜（膜厚：400-1500 nm）は ITO ガラス基板上に $\mathrm{CuSbS}_{2}$ ナノロッドを含ん だインク溶液をドロップキャストすることによ り製膜した。表面に配位したオレイルアミンは 膜の電子輸送を阻害するため, ナノ結晶用いた 電子デバイスを作製する際には粒子表面のオレ イルアミンを取り除かなければならない。そこ で，メーヤワイン試薬 $\left(\mathrm{C}_{2} \mathrm{H}_{5}\right)_{3} \mathrm{OBF}_{4}$ を用いてナ ノロッド表面からのオレイルアミンの除去を 行った。メーヤワイン試薬といった強いアルキ ル化剂と反応させることでオレイルアミンは四 級アミンへと変換でき，これによりナノ結晶表 面への配位能力が減少するため, 洗浄によって アミンを除去することができた。また，これら のアルキル化剂は金属硫化物とは反応しないの で，粒子表面を腐食することは無い. CdS バッ ファ層（膜厚 $30 \mathrm{~nm}$ ）は成膜した $\mathrm{CuSbS}_{2}$ 層の 上に化学溶液析出法を用いて成膜した。最後に
$\mathrm{Al} / \mathrm{CdS} / \mathrm{CuSbS}_{2} / \mathrm{ITO}-\mathrm{Glass}$

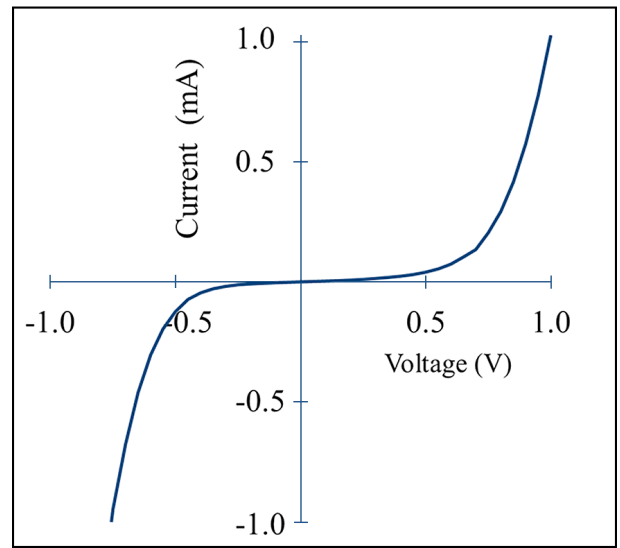

図 $4 \mathrm{Al} / \mathrm{CdS} / \mathrm{CuSbS}_{2} / \mathrm{ITO}$-glass 構造のデバイスの電 流-電圧 $(\mathrm{I}-\mathrm{V})$ 特性

$\mathrm{Al}$ 電極を真空加熱蒸着により取り付けてデバ イスを作製した。

図 4 に $\mathrm{CuSbS}_{2}$ ナノロッドの電流 - 電圧 $(\mathrm{I}-\mathrm{V})$ 特性を示す。このデバイスからは非線形な IV 特性が見られた。しかし逆バイアス側に大きな リーク電流が見られ，この構造では pn 接合が 良好ではない。理由としては，SEM 像から明 らかなように $\mathrm{CuSbS}_{2}$ 膜が粗いため, $\mathrm{CdS}$ との 接合が不良であることが原因と考えられる。

そこでデバイス構造を修正して, $\mathrm{ITO} / \mathrm{ZnO} /$ $\mathrm{CdS} / \mathrm{CuSbS}_{2} / \mathrm{Au}$ 構造の太陽電池を作製した. $\mathrm{ITO}$ 上に $\mathrm{ZnO}$ ナノ結晶をドロップキャストす ることにより, $\mathrm{ZnO}$ 膜を作製した。 この $\mathrm{ZnO}$ 薄膜は $300^{\circ} \mathrm{C}$ で 30 分間加熱して表面から有機 物を除去した。 $\mathrm{CdS}$ バッファ層（膜厚 $30 \mathrm{~nm}$ ） は成膜した $\mathrm{ZnO}$ 層の上に化学溶液析出法を用 いて成膜した， $\mathrm{nO}$ を製膜した基板をホット プレートで $90^{\circ} \mathrm{C}$ まで加熱し， $0.015 \mathrm{M}$ の硫酸 カドミウムと $1.5 \mathrm{M}$ のチオ尿素水溶液 (分量比 1:1）の混合溶液を基板に滴下した。この時の $\mathrm{pH}$ 值はアンモニア水溶液を用いて 10 程度に調 整した。 3 分間加熱を行った後，基板を取り出 して純水でよく洗浄・乾燥を行った。この $\mathrm{CdS}$ 層上に $\mathrm{CuSbS}_{2}$ 光吸収層（膜厚：500-1500 nm） を成膜した。トルエンに分散させた $\mathrm{CuSbS}_{2}$ ナ ノ結晶の溶液 $(0.23 \mathrm{mg} / \mathrm{ml})$ をスピンコーティ ング（回転数 $2000 \mathrm{rpm} ）$ することで, $\mathrm{CuSbS}_{2}$ 


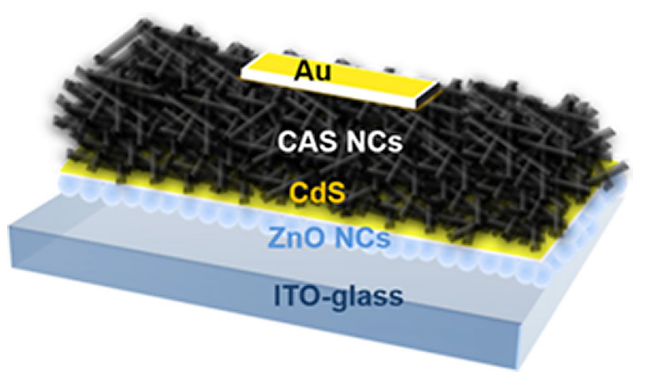

図 5 作製した太陽電池の模式図 $\left(\mathrm{Au} / \mathrm{CuSbS}_{2} / \mathrm{CdS} /\right.$ $\mathrm{ZnO} \mathrm{NCs} / \mathrm{ITO}$-glass 構造)

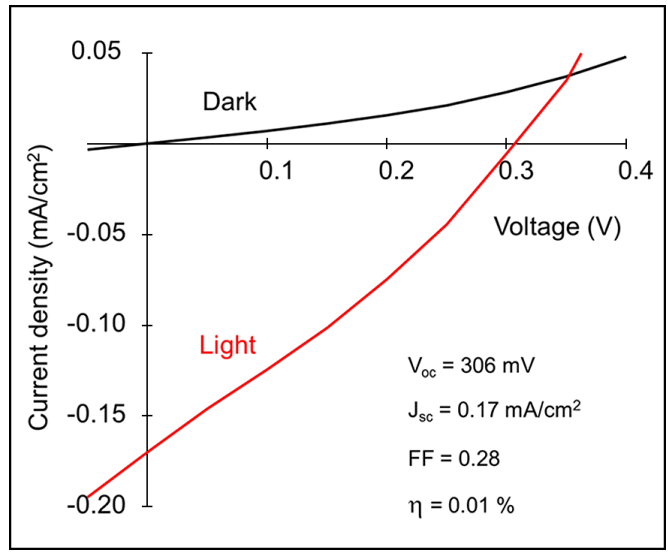

図 $6 \mathrm{Au} / \mathrm{CuSbS}_{2} / \mathrm{CdS} / \mathrm{ZnO} \mathrm{NCs} / \mathrm{ITO}$-glass 構造のデバ イスの電流 - 電圧 $(I-V)$ 特性. 光照射時 (赤 線) および暗時（黒線）

光吸収層を作製した。さらに上述した手法によ り結晶表面に吸着した配位子(オレイルアミン) を除去した，最後に金電極を真空加熱蒸着によ り取り付け, Glass/ITO/ZnO/CdS/CuSbS $2 / \mathrm{Au}$ の デバイス構造を作製した（図 5).

太陽電池測定は Keithly 2400 のソースメー ターを用いて AM1.5 $\left(100 \mathrm{~mW} / \mathrm{cm}^{2}\right)$ の擬似太 陽照射下で行った，図 6 に $\mathrm{CuSbS}_{2}$ 太陽電池の 電流一電圧 $(I-V)$ 特性を示す. 明瞭な光誘起 整流特性を観測し, 光電変換効率は $0.01 \%$ で あった。また開放電圧 $\left(V_{\mathrm{OC}}\right)$ は $306 \mathrm{mV}$, 短絡 電流值 $\left(J_{\mathrm{sc}}\right)$ は $0.17 \mathrm{~mA} / \mathrm{cm}^{2}$, 曲率因子は $(F F)$ は 0.28 であった。本実験で作製した太陽電池 の変換効率は非常に低いが, 太陽電池光吸収層 として $\mathrm{CuSbS}_{2}$ ナノロッドが作用することを明 らかにできた

\section{まとめ}

ホットインジェクション法を用いて $\mathrm{CuSbS}_{2}$ ナノ結晶の合成を行った. $\mathrm{CuSbS}_{2}$ ナノ結晶は 約 $50 \mathrm{~nm} \times 1 \mu \mathrm{m}$ のロッド形状を有していた. UV-Vis-NIR スペクトルから $\mathrm{CuSbS}_{2}$ ナノロッド の光学的禁制带幅を $1.3 \mathrm{eV}$ と見積もった。組 成比は $\mathrm{Cu}_{1.0} \mathrm{Sb}_{1.0} \mathrm{~S}_{1.7}$ と硫黄が少し欠損した状態 であった. $\mathrm{CuSbS}_{2}$ ナノロッドを $\mathrm{n}$ 型半導体で ある $\mathrm{CdS}$ と組み合わせてデバイスを作製した ところ，ダイオード特性を観測した。ささらに， $\mathrm{Au} / \mathrm{CuSbS}_{2} / \mathrm{CdS} / \mathrm{ZnO} \mathrm{NCs} / \mathrm{ITO}$-glass 構造の太陽 電池に拀いて, 明瞭な光誘起整流特性を観測す ることができた，変換効率：0.01\%, 開放電圧 $\left(V_{\mathrm{OC}}\right): 306 \mathrm{mV}$, 短絡電流值 $\left(J_{\mathrm{sc}}\right): 0.17 \mathrm{~mA} / \mathrm{cm}^{2}$, 曲率因子 $(F F) ： 0.28$ であった。

本研究では, アルキル化剂を用いて加熱処理 をすることなくナノ結晶太陽電池を作製した. この手法は手早く太陽電池を作製することがで きるため, 太陽電池用の光吸収材料の探索に向 いている，今後，このナノ結晶を用いた成膜プ ロセス利用することで, 種々の材料 $(\mathrm{Cu}-\mathrm{Sb}-\mathrm{S}$ 系や Cu-Bi-S 系）の光吸収特性をスクリーニン グする計画である。

\section{参考文献}

[1] Britt, J.; Ferekides, C. Thin film CdS/CdTe Solar Cell with 15.8\% Efficiency. Appl. Phys. Lett. 1993, 62, 2851-2852.

[2] Green, M. A.; Emery, K.; Hishikawa, Y.; Warta, W. Solar Cell Efficiency Tables (version 36). Prog. Photovolt: Res. Appl. 2010, 18, 346-352.

[3] Kumar, M.; and Persson, C.; $\mathrm{CuSbS}_{2}$ and $\mathrm{CuBiS}_{2}$ as Potential Absorber Materials for Thin-Film Solar Cells. J. Renewable Sustainable Energy 2013, 5, 031616031621.

[4] Dufton, J. T. R.; Walsh, A.; Panchmatia, P. M.; Peter, L. M.; Colombara, D.; Islam, M. S. Structural and Electronic Properties of $\mathrm{CuSbS}_{2}$ and $\mathrm{CuBiS}_{2}$ : Potential Absorber Materials for Thin-Film Solar Cells. Phys. Chem. Chem. Phys. 2012, 14, 7229-7233.

[5] Manolache, S.; Duta, A.; Isac, L.; Nanu. M.; Goossens, A.; Schoonman, J. The Influence of the Precursor Concentration on $\mathrm{CuSbS}_{2}$ Thin Films Deposited from Aqueous Solutions. Thin Solid Films, 2007, 515, 5957- 
5960.

[6] Rabhi, A.; Kanzari M.; Rezig B. Growth and Vacuum Post-annealing Effect on the Properties of the New Absorber $\mathrm{CuSbS}_{2}$ Thin Films. Mater. Lett. 2008, 62, 35763578 .

[7] Nair, M. T. S.; Peña, Y.; Campos, J.; Garcia, V. M.; Nair, P. K. Chemically Deposited $\mathrm{Sb}_{2} \mathrm{~S}_{3}$ and $\mathrm{Sb}_{2} \mathrm{~S}_{3}-\mathrm{CuS}$ Thin Films. J. Electrochem. Soc. 1998, 145, 21132120.

[8] Rabhi, A.; Kanzari, M.; Rezig. B. Optical and Structural Properties of CuSbS2 Thin Films Grown by Thermal Evaporation Method. Thin Solid Films, 2009, 517, 2477-2480.

[9] Colombara, D.; Peter, L. M.; Rogers K. D.; Hutchings K. Thermochemical and Kinetic Aspects of the Sulfurization of $\mathrm{Cu}-\mathrm{Sb}$ and $\mathrm{Cu}-\mathrm{Bi}$ Thin Films. J. Solid State Chem. 2012, 36-46.

[10] Lazcano, Y. R-.; Nair, M. T. S.; Nair, P. K. Photovoltaic p-i-n Structure of $\mathrm{Sb}_{2} \mathrm{~S}_{3}$ and $\mathrm{CuSbS}_{2}$ Absorber Films Obtained via Chemical Bath Deposition. J. Electro-

\section{外部 発表成果}

\section{論文発表}

1. Satoshi Suehiro, Keisuke Horita, Masayoshi Yuasa, Tooru Tanaka, Katsuhiko Fujita, Yoichi Ishiwata, Kengo Shimanoe and Tetsuya Kida, Synthesis of Copper-Antimony-Sulfide Nanocrystals for Solution-Processed Solar Cells, Inorganic Chemistry, 54 (2015), 7840-7845. chem. Soc., 2005, 152, G635-G638.

[11] Panthani, M. G.; Akhavan,V.; Goodfellow, B.; Schmidtke, J. P.; Dunn, L.; Dodabalapur, A.; Barbara, P. F.; Korgel, B. A. Synthesis of $\mathrm{CuInS}_{2}, \mathrm{CuInSe}_{2}$, and $\mathrm{Cu}\left(\operatorname{In}_{x} \mathrm{Ga}_{1-x}\right)$ $\mathrm{Se}_{2}$ (CIGS) Nanocrystal "Inks" for Printable Photovoltaics. J. Am. Chem. Soc. 2008, 130, 16770-16777.

[12] Xie, R.; Rutherford, M.; Peng, X. Formation of High-Quality I-III-VI Semiconductor Nanocrystals by Tuning Relative Reactivity of Cationic Precursors. $J$. Am. Chem. Soc. 2009, 131, 5691-5697.

[13] Li, L.; Coates, N.; Moses D.; Solution-Processed Inorganic Solar Cell Based on in Situ Synthesis and Film Deposition of $\mathrm{CuInS}_{2}$ Nanocrystals. J. Am. Chem. Soc. 2010, 132, 22-23.

[14] Scheunemann, D.; Wilken, S.; Parisi, J.; Borchert, H. Appl. Phys. Lett. 2013, 103, 133902-133906.

[15] Yan, C.; Su, Z.; Gu, E.; Cao, T.; Yang, J.; Liu, J.; Liu, F.; Lai, Y.;Lia J.; Liua Y. Solution-Based Synthesis of Chalcostibite $\left(\mathrm{CuSbS}_{2}\right)$ Nanobricks for Solar Energy Conversion. RSC Adv. 2012, 2, 10481-10484.

\section{口頭・ポスター発表}

1. Keisuke Horita, Satoshi Suehiro, Masayoshi Yuasa, Tetsuya Kida, and Kengo Shimanoe, " $\mathrm{Cu}_{2} \mathrm{ZnSnS}_{4}$ Nanocrystal Solar Cells Using Solution Processes", The 15th IUMRS-ICA (International Union of Materials Research Societies, International Conference in Asia) (Fukuoka, Japan, 24 August, 2014) 